\title{
THE ASSOCIATION OF KNOWLEDGE AND ATTITUDE WITH HAND HYGIENE COMPLIANCE AMONG HEALTH PERSONNEL AT THE EMERGENCY DEPARTMENT IN PRIVATE HOSPITALS, SURAKARTA
}

\author{
Nida Faradisa Fauziyah, Kusbaryanto \\ Public Health Program, Faculty of Health Science, \\ Universitas Muhammadiyah Surakarta
}

\begin{abstract}
Background: Hand hygiene is important in preventing nosocomial infection in hospital. The emergency department represents an environment with a high density of invasive and pathogens, hence the important sentinel functions of the emergency department personnel. This study aimed to determine the association between knowledge and attitude with hand hygiene compliance of emergency department personnels in private hospitals in Surakarta.

Subjects and Method: This was cross sectional study conducted at private hospitals in Surakarta, Central Java. Population in this study consisted of 50 personnel in emergency department private hospital selected by random sampling. The dependent variable was handwash compliance. The independent variables were knowledge and attitude on hand hygiene. Association between variables was measured by Pearson correlation.

Results: Personnel in the emergency department had moderate knowledge about hand hygiene (73.44\%), moderate hand hygiene attitude (64.6\%), and weak handwash compliance (42\%). There were almost non existent and statistically non significant correlations between knowledge $(\mathrm{r}=0.06 ; \mathrm{p}=0.703)$ and attitude $(\mathrm{r}=0.04 ; \mathrm{p}=0.686)$ with hand hygiene compliance.

Conclusion: Knowledge and attitude has almost non existent correlations with handwash compliance and they were not statistically significant.
\end{abstract}

Keywords: knowledge, attitude, handwash, hygiene, emergency department

\section{Corespondence:}

Nida Faradisa Fauziyah. Study programe in Hospital Management, Graduate School Universitas Muhammadiyah Yogyakarta. Email: nidafaradisa1991@gmail.com. Mobile: 087715476908. 